\title{
The Cenomanian-Turonian boundary problem in NW-Germany with comments on the north-south correlation to the Regensburg Area
}

\author{
GUNDOLF ERNST, CHRISTOPHER J. WOOD and HEINZ HILBRECHT
}

\begin{abstract}
Ernst, G., Wood, C. J. \& Hilbrecht, H.; The Cenomanian-Turonian boundary problem in NW-Germany with comments on the north-south correlation to the Regensburg Area. Bull. geol. Soc. Denmark, vol. 33, pp. 103-113, Copenhagen, September, 11th, 1984. https://doi.org/10.37570/bgsd-1984-33-08

The lithostratigraphical successions across the Cenomanian-Turonian boundary are described. Two different facies can be distinguished: A shallow water red marly limestone facies ('Rotpläner') characterised by evidence of condensation and stratigraphical hiati; and a more complete deeper water facies with alternating marly limestones and black shales ('Black Shales' or 'Schwarzweiße Wechselfolge'). A sequence of litho- and ecoevents permits subdivision and correlation of the two facies. The base of both facies is apparently isochronous and rests on white coccolith limestones, the so-called 'Arme rhotomagense Schichten' of the Upper Cenomanian Calycoceras naviculare Zone. The stage boundary was traditionally drawn at the facies change, but biostratigraphical evidence places the boundary within the Rotpläner/Black Shale formations.

In Lower Saxony the extinction datum of Rotalipora cushmani agrees with records from other areas, i.e. within the Upper Cenomanian Metoicoceras geslinianum Zone below the entry of Actinocamax plenus. From the Teutoburger Wald (Münsterland) and Regensburg area (Bavaria) an apparent diachroneity of this datum is indicated. The uppermost Cenomanian Neocardioceras juddii Zone of the international scheme has been identified only in the Black Shale facies. The diagnostic ammonites and inocaramid (Mytiloides aff. duplicostatus) of the basal Turonian Pseudaspidoceras flexuosum Zone have not been recorded in either facies. For practical purposes the base of the Turonian is taken at the entry of Mytiloides, as is usual in Central Erope. Below this level there is a 'zone of uncertainty' with poorly preserved inoceramids of questionable generic identity. Above the entry of recognizable Mytiloides, an interregional facies-independent Mytiloides mytiloides ecoevent is traceable across W.-Germany to eastern England.

Critical species concepts within Mytiloides are reviewed in the context of possible facies dependence. Of importance for the North-South correlation is the recognition of Mytiloides sp. at the base of the Praeglobotruncana helvetica Zone in the Regensburg area.
\end{abstract}

G. Ernst and H. Hilbrecht, Institut für Paläontologie der Freien Universität, Schwendenerstrasse 8, D-1000 Berlin 33, Germany; C. J. Wood, Palaeontology Unit, British Geological Survey, Exhibition Road, London SW7 2DE, England. March 8th, 1984.

\section{Introduction}

As part of the German contribution to the IUGS major project 'Mid-Cretaceous Events', the Berlin-Hannover working group undertook multistratigraphical investigation of the Cenomanian and Turonian in the area of NW Germany between Lower Saxony and western Westphalia (Fig. 1). Important results of this programme were published by, amongst others, Ernst \& Schmid (1979), Seibertz (1979a, 1979b), Ernst \& Schmid (1980), Keller (1982), Ernst, Schmid \& Seibertz (1983), Ernst \& Wood (1983), Kaplan \& Schmid (1983).

In the course of this investigation much new information was obtained on the CenomanianTuronian boundary. An outline of these results, reviewed within the context of the conclusions and recommendations of the 1983 Copenhagen Symposium on Cretaceous Stage Boundaries, is presented here. A more comprehensive account with details of the individual sections is in preparation.

The key area of this study lies between Salzgitter and Hannover (Lower Saxony) (Fig. 1). Within this area, there are numerous closelyspaced working limestone quarries, which provide excellent exposures of the CenomanianTuronian boundary succession in both shallow water (Rotpläner) and deeper water (Black 


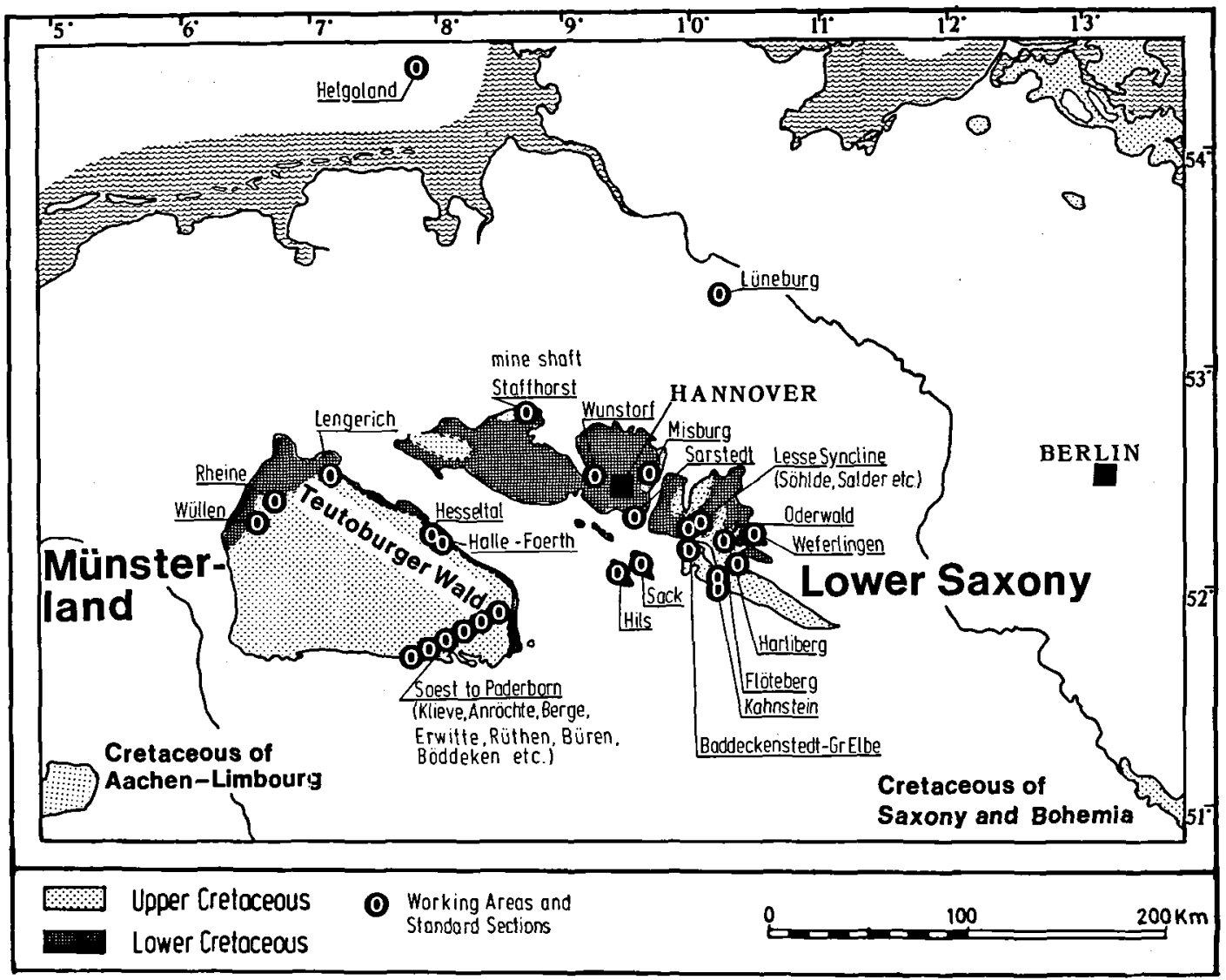

Fig. 1. Generalized map of Northern German Cretaceous outcrops with positions of important sections of the MCE Berlin and Hannover working groups.

Shales) facies. Many of these exposures are currently under investigation by undergraduate students of the Freie Universität Berlin, on whose results we have drawn extensively in this paper. In particular, we are indebted to D. Dahmer and A. Farman for data on the Söhlde area as well as H. Badaye and $\cdot R$. Kott for data on Baddeckenstedt.

The second important area comprises the northern margin (Teutoburger Wald) and western margin of the Münster 'Basin'. In the Teutoburger Wald the key localities are Hesseltal (Kaplan \& Schmid 1983) and Lengerich; in western Münsterland critical sections are Rheine and Wüllen. Investigation of these sections was undertaken in collaboration with U. Kaplan (Gütersloh).

Geographically and lithofacially intermediate between the two key areas is the isolated Sack syncline, which was documented by Schmid (1965) and Keller (1982).

Additional investigations in the context of the North-South correlation problem were made in the Regensburg area on the south side of the Mid-German High (sections of Bad Abbach and Benberg: Weiss 1982; Förster, Meyer \& Risch 1983).

\section{Lithostratigraphy of the Cenomanian- Turonian boundary succession}

The boundary succession falls within the so-called Plänerkalk Group (Ernst \& Schmid 1979), which is subdivided into five units of formation status. The units of relevance to the Cenomanian-Turonian boundary problem are the 'CenomanKalk' and the overlying Rotpläner/Black Shale (fig. 2).

The upper part of the 'Cenoman-Kalk' comprises pure white coccolith limestones, which, by reason of their poorly fossiliferous nature, are traditionally termed the 'Arme rhotoma- 


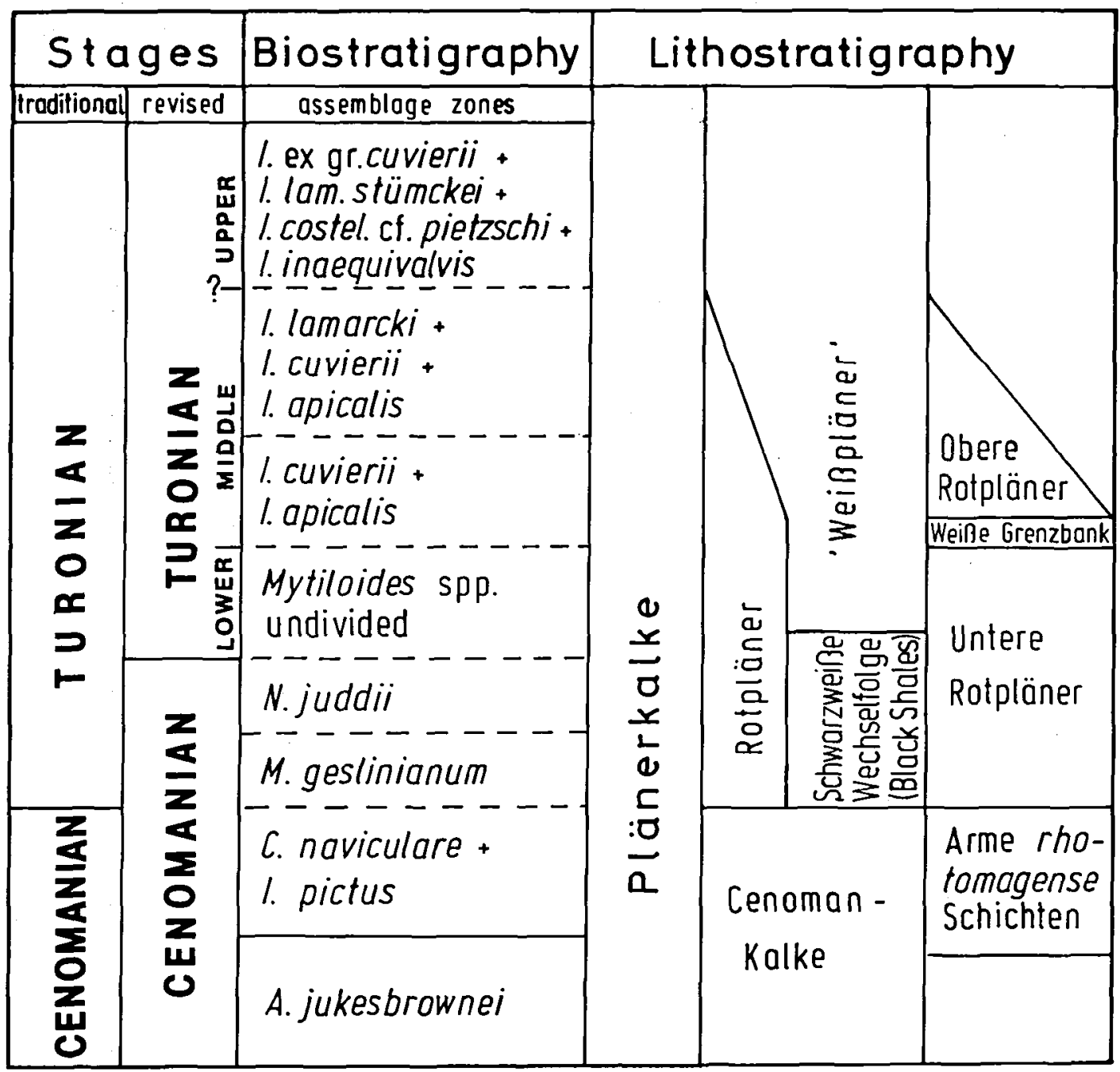

Fig. 2. The stratigraphy of the Cenomanian/Turonian boundary successions in NW-Germany. Provisional biozonation after Ernst, Schmid \& Seibertz (1983).

gense Schichten'. The traditional name of this unit is unfortunate, since it implies the occurrence of Acanthoceras rhotomagense, but in fact these beds constitute the Upper Cenomanian Calycoceras naviculare Zone (see Emst, Schmid \& Seibertz 1983), from which this ammonite is absent (fig. 2). At the top of this unit there is a dramatic facies change throughout NW-Germany. This facies change is an expression of a major intercontinental event, represented elsewhere in Europe by, for example, the change from the Regensburg Greensand to the Eibrunn Marls on the south side of the MidGerman High, by the subplenus erosion surface in southern England and the Antifer 1 Hardground in northern France.

In NW-Germany, the Cenomanian-Turonian boundary was traditionally drawn at the facies change, but biostratigraphical evidence places the boundary within the overlying Rotpläner/ Black Shale. The litho- and biostratigraphic characteristics of both units are discussed in detail below. a) Black Shale facies or Schwarzweisse Wechselfolge This facies comprises thick up to $30 \mathrm{~m}$ successions of alternating black or dark-grey laminated bituminous shales, pale chalky limestones, and greenish marls (fig. 3). This alternation reflects oscillating nearly anoxic and poorly oxygenated conditions. Bioturbation is well represented in nearly all units. The limestones are for the most part devoid of body fossils, but most of the black shales contain large thin-shelled inoceramids, flattened parallel to the lamination, together with fish scales and bones. In one bed in the Misburg succession flattened poorlypreserved pyritic moulds of ammonites co-occur with the inoceramids.

In northern Germany the Black Shale facies is best developed in three localities: (1) the Misburg HPCF II quarry in the fore-deep of the Lehrte-Sehnde Salt-dome, (2) the Wunstorf quarry in the Wunstorf syncline east of the Steinhuder Meer salt-structure, and (3) the Lengerich quarry on the north- 


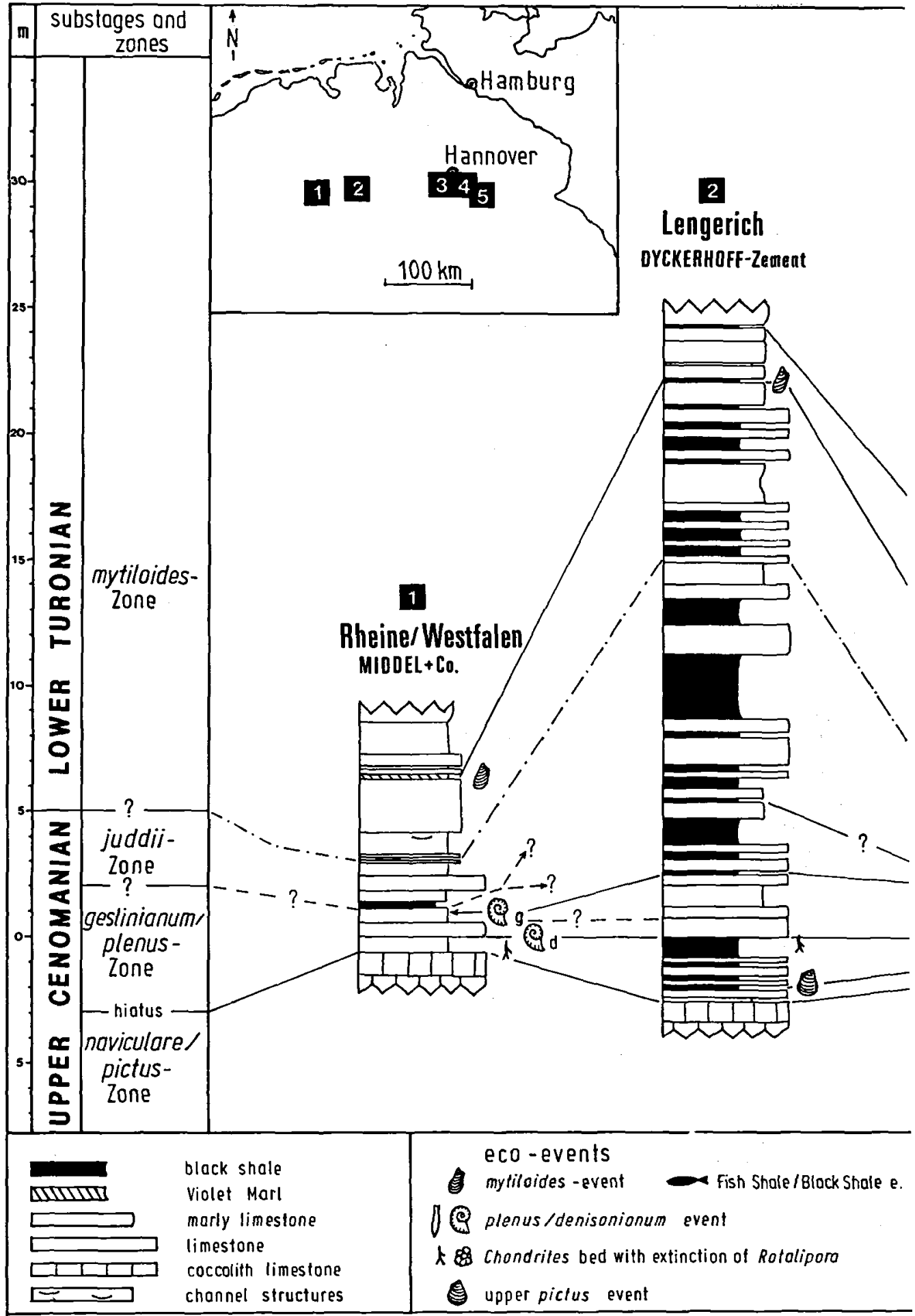

Correlation of Cenomanian/Turonian-boundary section 


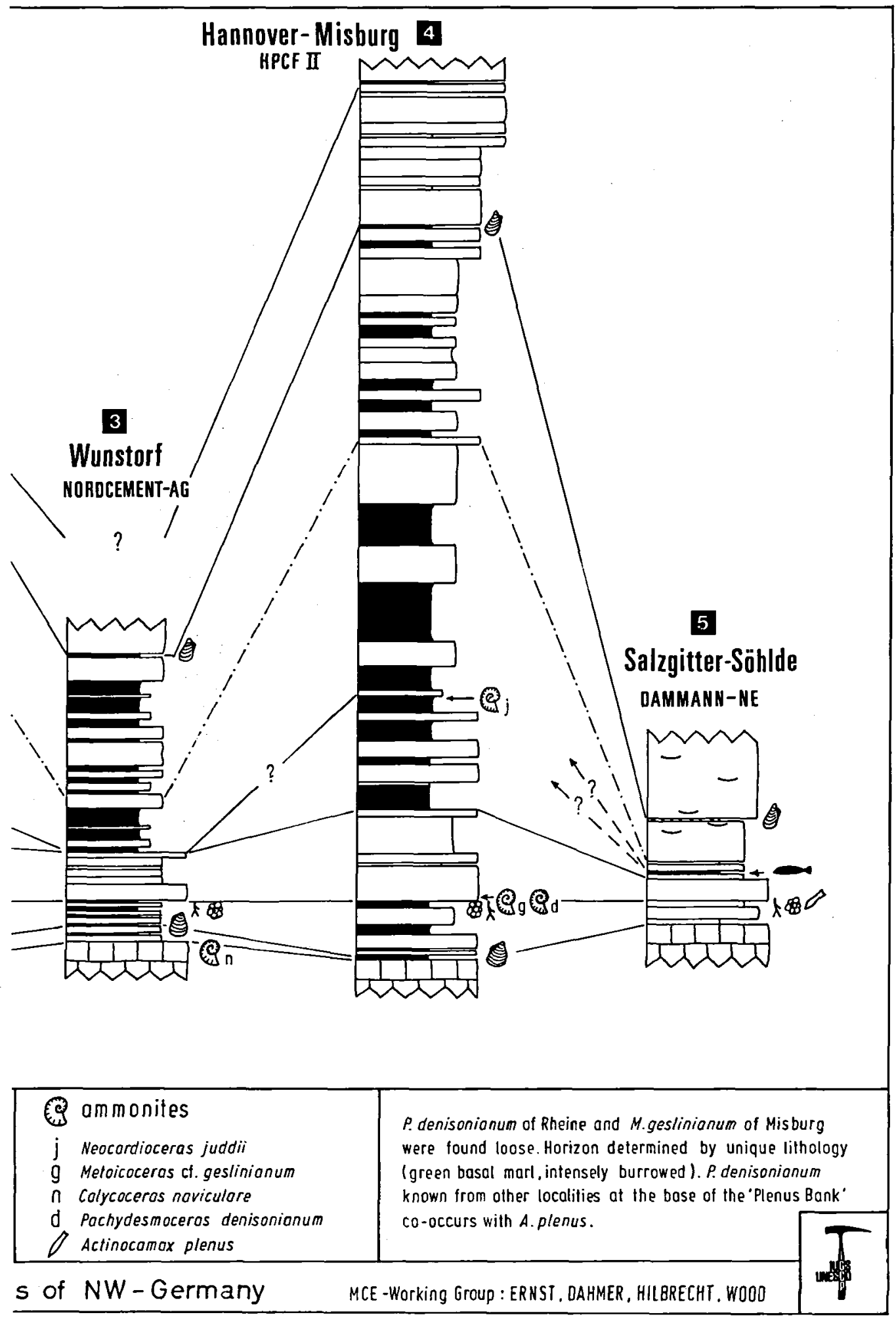

Fig. 3. Correlation of Cenomanian/Turonian-boundary sections of NW-Germany. 
ern margin of the Münster 'Basin' (fig. 4). Elsewhere in northern Germany, a $13 \mathrm{~m}$ black shale succession is found in the Sack syncline, where it is intercalated between two Rotpläner sequences (Keller 1982). Thin developments of the black shales are known from Lüneburg (Heinz 1928) and the offshore succession of Heligoland (Schmid \& Spaeth 1980).

In addition the black shale facies is well known from wells and boreholes in the North Sea basin, and a single black shale ('Black Band') is present onshore in eastern England. In fact, the black shale facies in the Cenomanian-Turonian boundary succession is found in many parts of the world and is an expression of a global anoxic event (for details see Schlanger, Arthur, Jenkyns \& Scholle, in press).

\section{b) Rotpläner facies}

This facies comprises predominantly red-coloured successions of marls and marly limestones, including green and violet marls. In contrast to the deeper water black shale facies, the Rotpläner facies was developed in a shallow water well oxygenated environment. In the deepest part of the Rotpläner succession, indications of extreme shallow water deposition are provided by intraformational pebbles, scour channels filled with fragmented shell debris, rapid lateral variations in thickness and sedimentary hiati (Ernst, Schmid \& Seibertz 1983, p. 550; D. Dahmer, unpublished thesis).

The Rotpläner facies is characterised by a low-diversity fauna, comprising mainly whole and fragmented inoceramids with subordinate terebratulid and rhynchonellid brachiopods. Echinoids are rare and the ammonites are almost all giant forms.

The Rotpläner facies is best developed in the Salzgitter area, notably in the northwestern part of the Lesse syncline, where a closely-spaced group of quarries near Söhlde permits a detailed study of lateral and vertical variation. Another excellent exposure is provided by the Baddeckenstedt quarry south of the halokinetically influenced Lichtenberg structure. The facies continues eastwards into the territory of the GDR (Ernst, Schmid \& Seibertz 1983, fig. 6). In the western part of the Münster 'Basin'there are Rotpläner successions similar to those in Lower Saxony, e.g. Wüllen and Rheine. In the Teutoburger Wald, however, the situation is more complex, and brightly coloured 'Rotpläner' beds are intercalated within the Lower part of the black shale succession, e.g. Hesseltal (Kaplan \& Schmid 1983) and Lengerich.

The base of the Rotpläner appears to be isochronous with the base of the black shale facies. The top of the Rotpläner Formation is diachronous, falling in some areas in the Lower Turonian (c.g. Sack syncline), and elsewhere within the Middle Turonian (Mittel-Turon), e.g. Salzgitter area (fig. 2).

\section{Biostratigraphy and events of the boundary succession}

Within the boundary succession there is a sequence of distinct litho and ecoevents, some of which permit correlation of the two facies. The most important events are the two Chondrites events, the plenus/denisonianium event, the Fish Shale/Black Shale event, the Neocardioceras event, and the Mytiloides mytiloides event. The positions of these are shown schematically in fig. 4.

a) Chondrites events

In the basal part of the succession in both facies are found two closely-spaced beds rich in the ichnofossil Chondrites. Of the two beds, the bioturbation is much greater in the upper and the Chondritis burrows are much more conspicuous. The ich- nofabric of the upper bed is covered by Bromley \& Ekdale (in press). The two events can be traced right across northern Germany from eastern Lower Saxony to Wüllen at the extreme western margin of the Münsterland. A comparable Chondrites event in an equivalent stratigraphical position occurs near the base of the Eibrunn Marls in the Regensburg 'Basin' (Bavaria) (Förster, Meyer \& Risch 1983). The extinction point of the planctonic foraminifer Rotalipora greenhornensis (Morrow) lies at the top of the lower, and that of $R$. cushmani (Morrow) at the top of the upper Chondrites event.

Between the lower Chondrites event and the facies change a well defined ecoevent, the upper pictus event, is found in Black Shale sections (fig. 3).

b) Plenus/denisonianum event

Immediately above the upper Chondrites event in the Rotpläner facies is a well-defined unit of pink and white mottled limestone, the so-called plenus Bank (Ernst, Schmid \& Seibertz 1983). This bed yields a distinctive fauna comprising extremely rare Actinocamax plenus (Blainville), together with Inoceramus pictus bohemicus Leonhard, Monteclarella jefferiesi Owen, Orbirhynchia wiesti (Quenstedt) and the giant ammonite Pachydesmoceras denisonianum (Stoliczka).

In the black shale facies the equivalent of the plenus Bank is poorly fossiliferous, except for rare badly preserved $I$. ex gr. pictus and the ammonites Metoicoceras geslinianum (d'Orbigny) (one specimen from Misburg), and P. denisonianum. Of the latter species, one specimen is known from Misburg, and numerous examples were recorded from a well exposed bedding-plane in the Hesseltal section (Kaplan \& Schmid 1983). In the Rotpläner section of Rheine U. Kaplan (personal communication) has found $M$. geslinianum likewise within the plenus Bank.

At the top of the plenus Bank there is a marked omissionsurface. The overlying succession is characterised by evidence of condensation, reworking, stratigraphical hiati, wedging-out of beds and synsedimentary tectonics (D. Dahmer, unpubl. thesis). The same situation obtains in the Eibrunn Marls, where it is restricted to the Whiteinella archaeocretacea planctonic foraminiferal Zone.

c) Fish Shale/Black Shale event

Within the Rotpläner facies there is one horizon that approximates to a black shale. This is best developed at Rheine, where it comprises a $10 \mathrm{~cm}$ dark grey shale within a typical Rotpläner succession. In Lower Saxony, this event is expressed as a thin marl rich in pyrite, compressed inoceramids of the pictus group and fish scales. The Fish Shale event is best seen in Baddeckenstedt (H. Badaye, unpubl. thesis). This event is believed to equate with the level of maximum development of black shale facies, i.e. the period of greatest oxygen depletion as indicated by black shales, richest in organic carbon, pyrite, and phosphate (fish debris). This black shale maximum comprises the Neocardioceras event and the black shales immediately above and below.

\section{d) Neocardioceras event}

This event is known so far only from Misburg, where it is situated approximately $11 \mathrm{~m}$ above the facies boundary within a $60 \mathrm{~cm}$ black shale unit. The ammonite assemblage, kindly identified by W. J. Kennedy and C. W. Wright (Oxford), comprises predominantly indeterminate Sciponoceras and Neocardioceras juddii (Barrois \& Guerne) with less common Allocrioceras sp. and Thomelites serotinus Wright \& Kennedy. This assemblage indicates the Neocardioceras juddii Zone of southern England and USA, commonly taken as the uppermost Cenomanian ammonite zone. The associated inoceramids appear to be two different large thin-shelled ecomorphs (or right and left valves) of the pictus group. The apparent absence of the Neocardioce- 


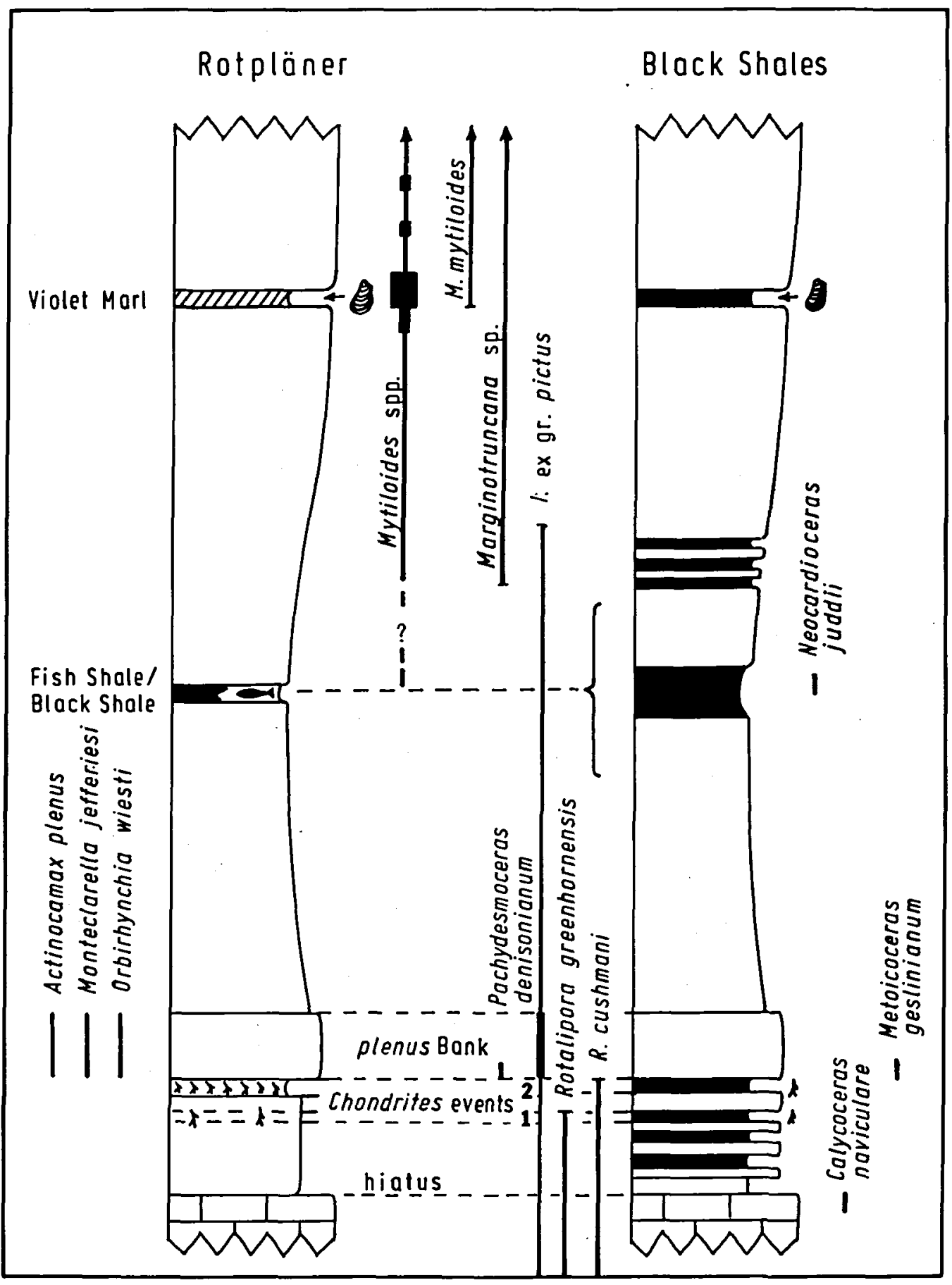

Fig. 4. Main events, lithological marker horizons, and ranges of critical taxa in the Cenomanian/Turonian boundary successions of NW-Germany. Not to scale. 
ras event from other black shale successions and from the Rotpläner is thought to be due to sedimentary hiati within the belt of anomalous sedimentation that begins on top of the plenus/denisonianum event.

e) Mytiloides mytiloides event

Following the entry of Mytiloides spp., a level of flood-occurrence of $M$. mytiloides (Mantell) is found in both facies. In the Rotpläner facies, the base of the event is marked by a distinctive $2-5 \mathrm{~cm}$ locally violet-coloured marl layer, the so-called 'Violet Marl'. This marl provides a lithostratigraphical marker that can be traced from Baddeckenstedt to Söhlde and which has now been identified in Rheine, where it is paler and thicker. In the black shale facies, this event marks the upper limit of black shale development. The base of the event is the uppermost black shale, which can thus be regarded as the correlative of the Violet Marl of the Rotpläner facies.

In the condensed succession above the 'Black Band' in eastern England (Wood \& Smith 1978), the M. mytiloides event is marked by a $10 \mathrm{~cm}$ orange marl, which is likewise the correlative of the Violet Marl, but which is lithologically closer to the development seen at Rheine.

\section{Criteria for recognising the base of the Turonian Stage}

At the Copenhagen Symposium on Cretaceous Stage Bondaries 1983 several proposals for recognising the base of the Turonian Stage were discussed. The most important of these were:

a) the extinction datum of Rotalipora cushmani

b) the base of the Pseudaspidoceras flexuosum ammonite Zone

c) the entry of the genus Mytiloides

Of these, there was a consensus favouring a combination of criteria $b$ and $c$, since these are believed to be approximately coincident and are in fact widely accepted by most workers. The extinction datum of Rotalipora cushmani is generally held to mark a major micropalaeontological bioevent within the higher part of the Cenomanian.

In the German Cenomanian-Turonian boundary successions, the application of any of the above criteria presents difficulty.

\section{a) The extinction datum of Rotalipora cushmani:}

This datum is known to fall within the Metoicoceras geslinianum Zone, and is one of the easiest bioevents to recognise in the boundary succession world-wide. The datum is usually considered to be globally isochronous, but the evidence from the German successions indicates a significant degree of apparent diachroneity (see discussion below). In the Rotpläner successions of Lower Saxony, the extinction level falls at the top of the upper Chondrites event, i.e. below the bed which yields Actinocamax plenus (plenus Bank). In the black shale facies, the datum is situated below a bed yielding Metoicoceras geslinianum. This biostratigraphical relationship closely corresponds to the faunal change across the Jefferies bed 3-4 boundary in the Plenus Marl of southern England (Carter \& Hart 1977). In the Münsterland the datum has been identified at the lower Chondrites event in the Hesseltal section (Koch in Schmid \& Kaplan 1983).

In the Regensburg 'Basin' the situation is extremely complex. In the Eibrunn Marl succession of Bad Abbach, from which Dacqué (1936) recorded Actinocamax plenus, the extinction datum falls below a marly limestone (Weiss 1982) that may be the equivalent of the plenus Bank of northern Germany. In the Benberg section, only some $10 \mathrm{~km}$ distant, a single Chondrites event is overlain by a marly limestone, and the succession at this level appears to be similar to that in northern Germany with the plenus Bank overlying the upper Chondrites event. In marked contrast to northern Germany, however, ammonites of the geslinianum Zone and Actinocamax plenus are found in both the Chondrites Bed and the marly limestone, and the extinction datum of $R$. cushmani is situated above the latter rather than below (Förster, Meyer \& Risch 1983). There is as yet no explanation for the apparent diachroneity of this datum, but it is noteworthy that there is evidence of reworking at the eastern margin of the Regensburg area and of extreme lateral thickness variation in the center of the basin (Förster, Meyer \& Risch 1983). These sedimentary anomalies occur at the same stratigraphical level as in northern Germany, i.e. within the Whiteinella archaeocretacea Zone. This problem requires further investigation.

\section{b-c) Base of Pseudaspidoceras flexuosum Zone/entry of Mytiloides}

As currently interpreted in USA (Cobban 1983), the base of the Turonian is recognised at the base of the Pseudaspidoceras flexuosum Zone, and the upper limit of the Cenomanian is taken at the top 
of the Neocardioceras juddii Zone. In addition to the zonal index, the $P$. flexuosum Zone is characterised by Watinoceras, and an undescribed species of Mytiloides, usually referred to as $M$. aff. duplicostatus (Anderson) (Kauffman \& Powell 1977). Indigenous Watinoceras and $M$. aff. duplicostatus are found immediately above reworked Neocardioceras juddii in the extremely condensed successions in south-west England (Devon) and northern France (P. Woodroof coll., Oxford). There is thus clear evidence for both zones of the north American boundary succession. Elsewhere in northern Europe, there is evidence generally only of the juddii Zone, and the lowest Turonian macrofaunas appear to belong to a higher level within the N. American scheme, i.e. the Mammites nodosoides Zone.

In northern Germany, the uppermost Cenomanian ammonite zone can be unequivocally identified at the level of the Neocardioceras event of the black shale facies. The recognition of the base of the Turonian of the American scheme is, however, extremely difficult in the absence of ammonites as it depends on the identification of the entry point of Mytiloides and/or of $M$. aff. duplicostatus. There is so far no evidence for the occurrence of $M$. aff. duplicostatus in the north German successions. In the Rotpläner facies, the entry of definite Mytiloides spp. is situated within the Fish-Shale-Violet Marl interval. Between this horizon and the Fish Shale only generically indeterminate fragmented inoceramids are present: The inoceramid assemblage with the lowest definite Mytiloides include inflated forms comparable to M. labiatus (Schlotheim) sensu Seitz (1935), together with subordinate flat mytiloid forms and small Inoceramus spp. including $I$. aff. apicalis Woods, and $I$. cf. apicalis s.s. There is evidence from Lower Saxony, particularly from the Söhlde area, that the inoceramid assemblages in the beds below the Violet Marl are facies-related, with Inoceramus apparently predominating in shallow water and Mytiloides in deeper water environments. At the level of the Violet Marl there is a significant change in the Mytiloides assemblages, with the entry of $M$. mytiloides. The latter species is elsewhere typically found associated with the ammonite Mammites nodosoides (Schlotheim).

In the Black Shale facies, the first definite $M y$ tiloides are found approximately at the base of a distinctive sequence of three thin closely-spaced black shales (Fig. 4), more or less coincident with the entry of the planctonic foraminiferal genus Marginotruncana (see Weiss 1982: 99). Between this horizon and the Neocardioceras event, complete inoceramids are restricted to the black shales and only comminuted fragments are found in the limestones. These inoceramids are not only difficult to collect, but they are badly preserved and in many cases represented only by pyritic moulds, so that generic identification presents problems. We believe, however, that both Mytiloides and Inoceramus of the pictus group are present in this interval. The inoceramid assemblages between the entry of Marginotruncana and the Mytiloides mytiloides event, although badly distorted by compaction and otherwise poorly preserved, appear to be generally comparable with those that occur below the Violet Marl in the Rotpläner facies.

In southern Germany, we have recently identified poorly preserved flattened moulds of definite Mytiloides sp. in the Eibrunn Marls of the Bad Abbach section at and above the entry datum of Praeglobotruncana helvetica. This discovery is of great importance for the correlation between Tethyan and Boreal successions.

We have experienced considerable difficulty in identifying the species of Mytiloides present in the Rotpläner facies. As indicated by Keller (1982), it is apparent that the supposedly hemisphere-wide sequence of Mytiloides established in N. America (e.g. Kauffman, Cobban \& Eicher 1978) cannot readily be applied in northern Germany. It must be emphasised that the species of Mytiloides in the American scheme were originally defined in Europe, and particularly in Germany, and it is therefore necessary to interpret these taxa as far as possible on the basis of topotype material. Many of these taxa were introduced and/or reviewed by Seitz (1935), who had at his disposal extensive material from both the Rotpläner facies of the Salzgitter area and from the 'Quader' sandstone facies of the territory of the GDR. Two key taxa in the American scheme are M. labiatus and M. submytiloides (Seitz). The type of M. labiatus is lost, but following Seitz, the species is currently interpreted on the basis of a specimen from the Rotpläner facies of Groß Döhren near Salzgitter (Seitz 1935, Pl. 38, fig. 1). The type of $M$. submytiloides is based on a specimen from the 'Quader' sandstone facies (Seitz, 
Pl. 37, fig. 1). In the American scheme, $M$. submytiloides is placed low in the Turonian, whilst $M$. labiatus is the index of the (Middle Turonian) zone succeeding the $M$. mytiloides Zone. Our detailed stratigraphical collecting shows that $M y$ tiloides generally comparable with the reference specimen of $M$. labiatus from Groß Döhren could occur both above and below the $M$. mytiloides event at the Violet Marl, i.e. results significantly at variance with the sequence reported from North America. We have, however, based our interpretation of this species on the illustration by Seitz, as we have not so far been able to examine the actual specimen, which is in the "Zentralinstitut « of the Geological Survey of the GDR.

We have, similarly, felt that it was unwise to apply 'Quader' sandstone taxa, e.g. $M$. submytiloides, to Rotpläner material in view of the apparent facies-dependence of inoceramids within different depth zones of the Rotpläner facies itself, but note that specimens comparable to $M$. submytiloides as interpreted by both Kauffman (in Kauffman et al. 1978) and Keller (1982), are present as rarities in the assemblage from below the mytiloides event. It must be emphasized, however, that Inoceramus labiatus n.var. submytiloides [sic] as established by Seitz is based on two distinct morphotypes which he regarded as extreme forms. The rare Rotpläner facies specimens of $M$. cf. submytiloides sensu Kauffman, Keller differ from the 'Quader' steinkerns in the absence of the more or less distinctive furrow behind the anterior margin which characterises both morphotypes.

In conclusion, it is not possible to recognise the base of the Turonian stage unequivocally in the northern German succession, although it is possible to indicate its approximate position, i.e. at the top of the Neocardioceras event or within the interval between this event and the entry of Mytiloides. The use of the extinction datum of Rotalipora cushmani as a possible alternative is clearly inappropriate in view of the evidence that the datum may be diachronous.
Acknowledgements. The paper is a contribution to the IGCP Major Project 58 "Mid-Cretaceous Events" of the IUGS. Nationally supported by the Deutsche Forschungsgemeinschaft. C. J. Wood publishes by permission of the Director BGS (NERC). We thank all firms and quarry owners for granting us access to their quarries, and in particular the management of the HANNOVERSCHE PORTLAND-CEMENTFABRIK AG (HPCF) in Misburg, the NORDCEMENT AG, Werk Wunstorf, the DYCKERHOFF Zementwerke AG, Werksgruppe Lengerich, and the Kalkwerk Hollekamp \& Sohn, Wüllen.

\section{Dansk sammendrag}

Lithologi og biostratigrafi omkring cenomanien-turonien gransen $i$ den nordvestlige del af Vesttyskland er beskrevet. På basis af lithologiske, biostratigrafiske og økologiske mevents « er de to karakteristiske facies »Rotpläner « og »Schwarzweisse Wechselfolge« korreleret og underopdelt. Den øvre cenomane Neocadioceras juddii zone er kun identificeret i sidstnzvnte facies. Af praktiske årsager drages basis af turonien ved første bestemmelige forekomst af Mytiloides. Artsafgransningen af en rakke Mytiloides arter er kritisk vurderet.

\section{References}

Bromley, R. G. \& Ekdale, A. A. in press: Chondrites: a trace fossil indicator of anoxia in sediments. Science.

Carter, D. J. \& Hart, M. B. 1977: Aspects of mid-Cretaceous Stratigraphical Micropalaeontology. Bull. Br. Mus. nat. Hist. (Geol.); 29, 1-135, London.

Cobban, W. A. 1983: Mid-Cretaceous ammonite zones, Western Interior, United States. Symp. Cretaceous Stage Boundaries, Abstracts: 37-38, Copenhagen.

Dacqué, E. 1936: Die Fauna der Regensburg-Kelheimer Oberkreide (mit Ausschluß der Spongien und Bryozoen). $\boldsymbol{A} b \boldsymbol{h}$. Bayr. Akad. Wiss., math.-nat. Abt., N.F., 45, 218 p., München.

Ernst, G. \& Schmid, F. 1979: Multistratigraphische Untersuchungen in der Oberkreide des Raumes BraunschweigHannover. Aspekte der Kreide Europas. IUGS Ser. A,6, 11-46, Stuttgart.

Ernst, G. \& Schmid, F. 1980: The Upper Cretaceous of Central and Eastern Lower Saxony. In: Birkelund, T. \& Bromley, R. G.; Upper Cretaceous of NW Europe. Guide to Excursion A-69, 26th Intern. Geol. Congr. Paris, 83-113, Paris.

Ernst, G., Schmid, F. \& Seibertz, E. 1983: Event-Stratigraphie im Cenoman und Turon von NW-Deutschland. Zitteliana, 10, 531-554, München.

Ernst, G. \& Wood, C. J. 1983: Turonian stage and substage boundaries in the Plänerkalk Formation of Lower Saxony (Germany). Symp. Cretaceous Stage Boundaries, $A b$ stracts, 43-46, Copenhagen.

Förster, R., Meyer, R. \& Risch, H. 1983: Ammoniten und planktonische Foraminiferen aus den Eibrunner Mergeln (Regensburger Kreide, Nordostbayern). Zitteliana, 10, 123-141, München.

Heinz, R. 1928: Über Cenoman und Turon bei Wunstorf westlich Hannover. Jber. nieders. geol. Ver., 21, 18-38, Hannover.

Kaplan, U. \& Schmid, F. 1983: Der Großammonit Pachydesmoceras denisonianum (Stoliczka) und die Feinstratigraphie des hohen Ober-Cenoman im Hesseltal bei Halle in Westfalen (NW-Deutschland). Veröff. Naturkde - Mus. Bielefeld, 5, 1-20, Bielefeld. 
Kauffman, E. G., Cobban, W. A. \& Eicher, D. L. 1978: Albian through Lower Coniacian strata, biostratigraphy and principal events, Western Interior United States. Ann. Mus. d'Hist. nat. Nice 4, 1976, Mid-Cretaceous Events, reports on the biostratigraphy of key areas, XXIII. 1-52, Nice.

Kauffmann, E. G., Hattin, D. E. \& Powell, J. D. 1977; Stratigraphic, paleontologic and paleoenvironmental analysis of the Upper Cretaceous rocks of Cimarron County, Northwestern Oklahoma Mem. geol. Soc. America 149, 150 pp., Boulder, Colorado.

Keller, S. 1982: Die Oberkreide der Sack-Mulde bei Alfeld (Cenoman-Unter-Coniac): Lithologie, Biostratigraphie und Inoceramen. Geol. Jb., A 64, 3-171, Hannover.

Schlanger, S. O., Arthur, M. A., Jenkyns, H. C. \& Scholle P. A. in press: The Cenomanian-Turonian oceanic anoxic event, I. Stratigraphy and distribution of organic carbonrich beds and the marine $\delta{ }^{13} \mathrm{C}$ excursion. In Brooks, J. \& Fleet, A. (Eds.). Marine Petroleum Source Rocks, Geol. Soc. London, spec. Publ.

Schmid, F. 1965: Actinocamax plenus (Blainville) ein seltener Belemnitenfund im Rotpläner (Oberkreide, Niedersachsen). Geol. Jb., 83, 517-532, Hannover.
Schmid, F. \& Spaeth, C. 1980: Erster Nachweis von Schwarzschiefern im Unter-Turon Helgolands (Nordsee, NW-Deutschland). N. Jb. Geol. Paläont. Mh., 1980, 11, 703-706, Stuttgart.

Seibertz, E. 1979a: Biostratigraphie im Turon des SE-Münsterlandes und Anpassung an die internationale Gliederung aufgrund von Vergleichen mit anderen Oberkreide-Gebieten. Newsl. Stratigr., 8, 2, 111-123, Berlin, Stuttgart.

Seibertz, E, 1979b: Stratigraphisch-fazielle Entwicklung des Turon im südöstlichen Münsterland (Oberkreide, NW-Deutschland). Newsl. Stratigr., 8. 1. 3-60, Berlin, Stuttgart.

Seitz, O. 1934: Die Variabilităt des Inoceramus labiatus v. Schlotheim. Jb. preuß. geol. Landesanst., 55, 429-474, Berlin.

Weiss, W. 1982: Planktonische Foraminiferen aus dem Cenoman und Turon von Nordwest- und Süddeutschland. Palaeontographica, Abt. A, 178, 1-3, 49-108, Stuttgart.

Wood, C. J. \& Smith, E. G. 1978: Lithostratigraphical classification of the Chalk in North Yorkshire, Humberside and Lincolnshire. Proc. Yorks. Geol. Soc., 42, 263-287. 